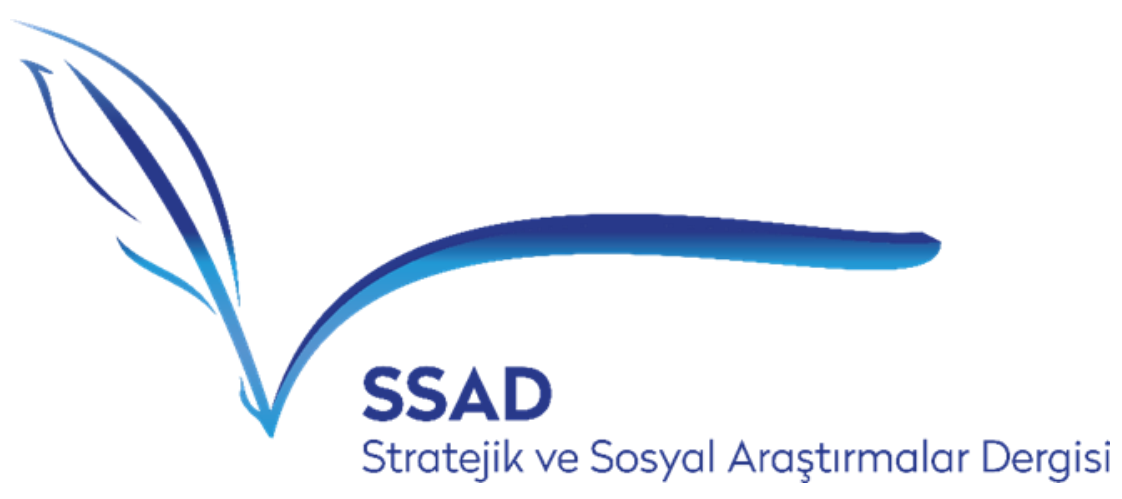

ISSN: 2587-2621

Volume 4 Issue 1, March 2020

ORCID ID: 0000-0002-5304-6948

Makale Gönderim Tarihi: 07.01.2020

Makale Kabul Tarihi: 11.03.2020

https://doi.org/10.30692/sisad.668234

\title{
CREATIVE STRATEGIES On TURKISH TELEVISION ADVERTISING: AN APPLICATION of TAYLOR'S SIX-SEGMENT MESSAGE STRATEGY WHEEL
}

\section{Türk Televizyon Reklamlarında Kullanılan Yaratıcı Stratejiler: Taylor'un Altı Segmentli Mesaj Stratejisi Üzerine Uygulama}

\author{
Özge ULUĞ YURTTAŞ \\ Dr. $\ddot{O} \breve{g r}$. Üyesi \\ Beykent Üniversitesi, İletişim Fakültesi, Halkla İlişkiler ve Reklamcılık \\ ozge.uyurttas@gmail.com \\ Yelda ÖZKOÇAK \\ Doç. Dr. \\ Doğuş Üniversitesi, Fen Edebiyat Fakültesi, İletişim Bilimleri \\ yozkocak@dogus.edu.tr
}

\begin{abstract}
TV}$ stations with the highest ratings among Turkish National TV Stations in December 2018 were examined in the study. Analyzing the advertisements with the content analysis method within Taylor's six-segment message strategy wheel, the reruns of the commercials were excluded, leaving 320 commercials to be examined according to their message strategies. Taylor's six-segment message strategy wheel constituted the theoretical framework of this study, allowing to analyze the communication approach (transmission or ritual) and message strategy (ego, social, sensory, routine, acute need, or ration) of Turkish television advertisements. Gathered data revealed $65 \%$ of the advertisements used transmission view with 94 of 320 ads being in rational segment. Among all advertisements ritual view was used in $35 \%$.
\end{abstract}


Keywords: Advertising, TV Advertising, Creative Strategies, Taylor's Six Segment Message Strategy, Content Analysis

Özet: Çalışmada Aralık 2018'de Türk Ulusal Televizyon kanalları içerisinde en çok izlenme oranına sahip ilk 5 televizyon kanalında, prime time saat aralığında yayımlanan toplam 2871 reklam incelenmiştir. Taylor'ın altı segmentli mesaj stratejisi çerçevesinde içerik analizi yöntemi ile incelenen reklamların tekrar yayınları çıkartılarak 320 reklamın mesaj stratejisi değerlendirilmiştir. Taylor'un altı segmentli mesaj stratejisinin teorik çerçeve olarak ele alındığı çalışmada Türk televizyon reklamlarında kullanılan ana iletişim yaklaşımını (ritüel ve aktarım) ve mesaj stratejisini (ego, sosyal, duyusal, rutin, akut ihtiyaç veya rasyonel) incelemektedir. Elde edilen önemli bulgular arasında aktarım görünümü kullanımına $65 \%$ oranında rastlanılmış, 320 reklamdan 94'ünde rasyonel segment kullanımı saptanmıştır. Bunun yanı sıra ritüel görünüm tüm reklamlarda 35\% oranında rastlanılmıştır.

Anahtar Kelimeler: Reklamcılık, TV Reklamcılı̆̆ı, Yaratıcı Stratejiler, Taylor'un Altı Segmentli Mesaj Stratejisi, İçerik Analizi.

\section{INTRODUCTION}

According to the general view, inscriptions and drawings aiming to promote goods in ancient times are considered first advertising practices. Technical and economic advancements, revolutions, the emergence of the global market contributed to advertising becoming popular among masses. From past to present, advertisements and the advertising industry have been growing and developing parallel to the growth and improvement of mass media and communication technologies.

Today, with the rise of digitalization, a substantial increase is observed in internet investments of advertising. Advertising Expenditure Forecasts Report of Zenith Media (2018) expresses that although television has been a dominant advertising medium between 1996 and 2016, along with the increase of internet advertising expenditures, it is expected of TV advertising shares to decrease (https://www.zenithmedia.com). The situation in Turkish advertising market is slightly different to that of the global market. According to the Media and Advertising Investment Report (2017) prepared by Advertisers Association in collaboration with Deloitte (https://www2.deloitte.com), total media investments increased by $6.3 \%$ compared to the previous year and with 2.2 billion US Dollars (47.8\%) television has the biggest share. These data indicate that unlike global media investments, the engine of the growth in Turkey is television. Advertising in Turkey started during Ottoman Empire with rudimentary practices such as town criers, barkers, venders, and countermen, leaving their place in time to announcements and publicity, eventually exhibited a rapid and major development with mass media such as newspapers, periodicals, radio and television. As stated in the Media and Advertising Investment Report, Turkey is the $26^{\text {th }}$ big market in terms of media and advertising investments, demonstrating consistent growth in TV investment between 2013 and 2017.

Within this scope, the growth of media and advertising investments - especially in television- in Turkey is remarkable. Therefore, this study aims to examine the message strategies of advertisements broadcast during commercial breaks of TV shows in the prime time (20.0023.00), which indicates the time slot with most TV audience watching television, of $5 \mathrm{TV}$ stations with the highest ratings in the groups of all people, $\mathrm{AB}$, and $20+\mathrm{ABC} 1$, according to data provided by TNS for December 2018 regarding Turkish National Television stations.

Within this context, the study commences by reviewing literature on television advertisements and creativity. Secondly, creative strategies used in advertisements are briefly explained and Taylor's (1999) six segment message strategy wheel is discussed. Eventually, methodology applied in the research is elaborated, research findings, suggestions, and results are presented.

\section{LITERATURE REVIEW ON ADVERTISING CREATIVITY}


Advertising occupies a significant place within life when considered the importance it bears in aspects such as mass media becoming more prominent from day to day, the development of marketing communication and the perceptional transformation, the construction of production and consumption manners, cultural communication. During the intense message exposure process of consumers, drawing the attention of target audience can only be provided through creative designs. Creativity in advertising refers to using different language, different construction of production which support increasing the appeal of advertisements. Creativity in consumer advertisements is commonly employed to strengthen ad efficiency (Samati and Khalili, 2017, p. 526). Therefore, creativity, which is a very important component of advertising, is deemed essential by both advertising agencies and clients.

Politz (1960), states that the biggest issue and equally important aspect of advertising is to discover the most efficient selling point of the brand, to which creativity can provide the most significant support. Koslow (2015), expresses that creativity in advertising has to be both original and appropriate, mentioning that the concept of appropriateness cannot be defined as simply as originality, therefore, explains that he considers this concept as appealing advertisement. Approaching from this angle, "creativity" is referred to as one of the most significant concepts for effective design (Baack et al., 2016; Smith and Yang, 2004)

Quite a lot of researchers use the terms message strategy and creative strategy interchangeably in their studies. However, even though the term is expressed with various approaches (Frazer 1983; Laskey, Day and Crask 1989; Taylor 1999), when defining creativity, Burton (cited by Elden, 2003) emphasizes the existence of two dominant views: for Ogilvy and Reeves creativity is "what to say", for Bernbach and Burnett "how to say". There has a distinction been made between the two terms in which message strategy is considered as what to say and creative strategy as how to say it.

Frazer (1983) regards creative strategy as instructive principles determining the general quality and character of the content designed for the advertisement message. Within this scope, Frazer proposes seven creative strategy sets applying for different message circumstances. These seven strategies comprise unique selling proposition, brand image, positioning, generic, preemptive, resonance and anomalous/affective. Laskey, Day and Crask (1989), on the other hand, prefer the term message strategies implying both message content and design. Laskey, Day and Crask created a classification for message strategy with two main categories and their sub-categories. The main categories are informational and transformational; the category informational including the sub-categories comparative, unique selling proposition, preemptive, hyperbole, generic-informational, the category transformational containing the sub-categories user image, brand image, user occasion and generic-transformational. AIIEE Strategies (Moriarty, 1991) known as creative message strategy in advertising is the abbreviation of the approaches argument, information, image, emotion, and entertainment. Argument and information approaches of AIIEE Strategies fall into rational category; image and emotion are handled separately, with entertainment being the last category. Taylor's six segment message strategy wheel, which he developed in this context, consists of two main parts with their sub-segments.

\subsection{Taylor's Six-Segment Strategy Wheel}

Taylor (1999) developed a six-segmented message strategy model, beyond the classifications created for creative advertising strategies. This model combines existing literature about message strategy into a single applicable model for professionals that they can easily employ in their advertising practices. Six segment message strategy wheel is based on social sciences and various theories originating from consumer behaviors. Taylor went through the ritual view (akin to transformational) and transmission view (akin to informational) but he also created three segments for each aspect (Tsourvakas et al., 2017, p. 343). Ritual view refers to emotional or sensory appeal of the message, whereas transmission view refers to the logical appeal (Golan and Zaidner, 2008). In the second level of Taylor's model, each part of the wheel (transmission 
and ritual) is divided into three segments. The structure with a total of six segments is based on an approach moving from macro to micro. The sub-segments are explained as follows:

The Freudian Psychoanalytic Model is the first segment in Taylor's message strategies used for products/services that the consumers purchase for making a personal, ego related statement. Ego refers to message strategies presenting product or service in a way defining who the consumer is and used for convincing the consumers that they will acquire the intended results when utilizing the product or service. The Veblenian Social Psychological Model is the second segment applied when the product or service is expected to make a statement to others. In other words, this message strategy refers to appealing advertisements for consumers visibly using the product/service in order to receive social approval from significant others, family, friends and other social relationships. The third segment called Cyrenaics includes products or services activating smell, touch, hearing, taste, or sight, in other words, the 5 senses. In Cyrenaics, message strategies commonly employ "moments of pleasure" (Taylor, 1999, p. 13)The previously elaborated segments belong to ritual view, whereas the three upcoming segments fall into transmission view. The Pavlovian Learning Model is the fourth segment. It indicates products that consumers buy due to habits. Consequently, the message strategy of this segment focuses on routine, habitual use of specific products or services. The acute need model, which is the fifth segment, is designed for channelizing the consumers into making purchase decisions for high-involvement products. Building brand familiarity, brand recognition, and consumer trust are the common strategies when applying this model (Ahn, 2013, p. 101). In the Marshallian Economic Model, which is the sixth segment, consumers are considered logical human beings who need to acquire information about a specific product/service in order to make a purchase decision. For this reason, this message strategy stands for advertisement messages with informational content to persuade the consumer, who needs product information, to purchase.

\section{Graphic 1. Taylor's Six Segment Message Strategy Wheel}

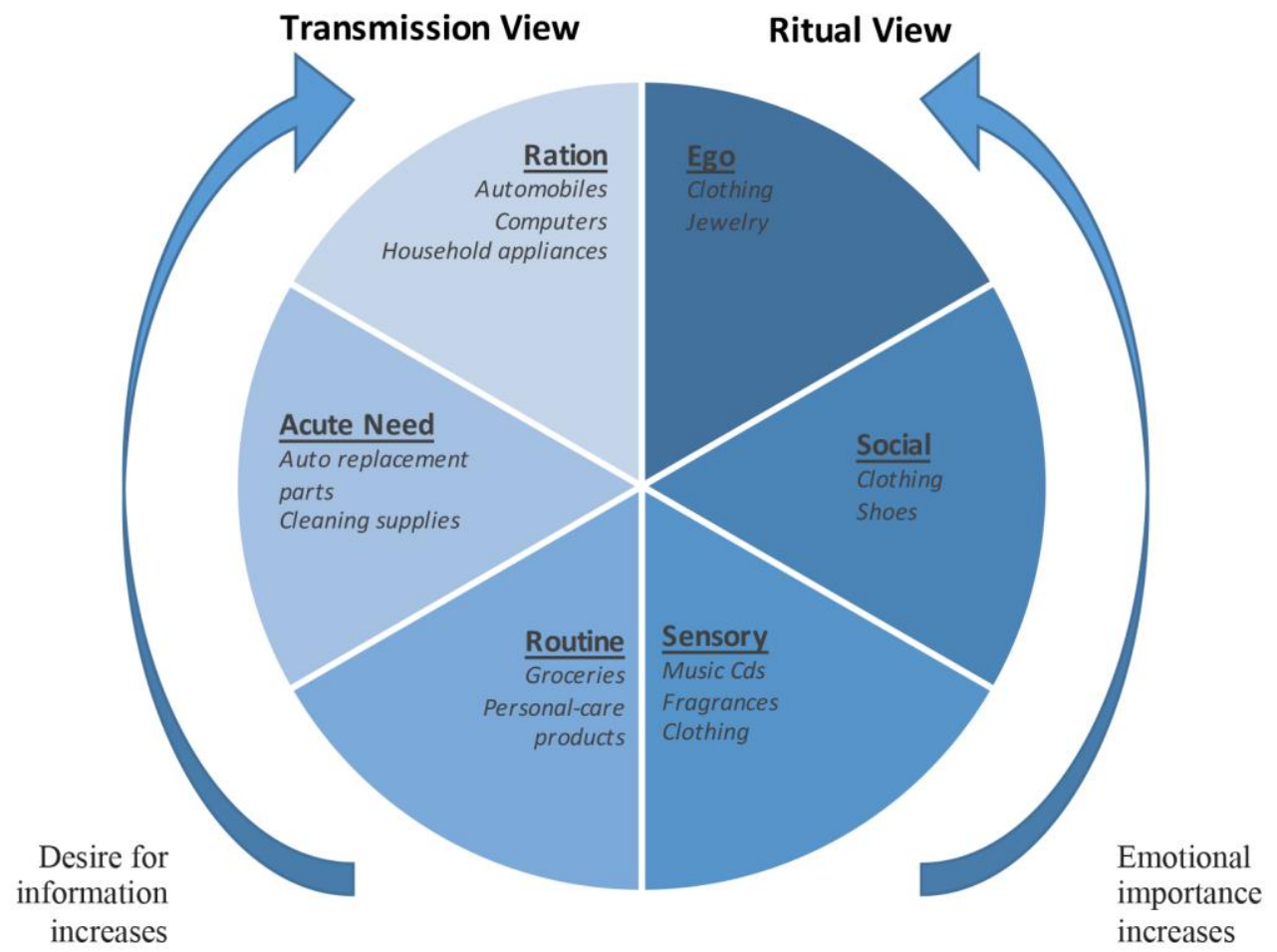

Source: Writers own - from different sources combination 
On the model with a vertical axis, the left side represents transmission view, the right side represents ritual view. The upper side includes the levels with highest impact on consumers in terms of rational or emotional importance. Within this context, the segments on the right side have an emotional impact on consumers, whereas the left side includes segments which the consumer needs with price or ration impact.

Kim et al. (2005, p. 49) assert that Taylor's model is extremely important due to two reasons. The authors base the first reason on the model handling the issue from the perspective of how people make purchasing decisions and how advertisements operate. The second reason is that the model pays equal attention to both transformational and informational advertisements and that a sophisticated reasoning is presented for defining the sub-segments.

Taylor's six segment message strategy model is applied comprehensively in various studies within literature with the purpose of examining and analyzing advertisement message strategies. Taylor's six segment message strategy model was employed in the studies, where Morrison and White (2000) analyzed Superbowl advertisements, Lee (2000) revealed the differences of automobile commercials broadcast in American and Korean televisions, Lee et al. (2001) compared the preferred message strategies of advertisements in the American and Korean television stations, Hwang et al. (2003) examined corporate websites as an advertising medium, Golan and Zaidner (2008) assessed creative strategies in viral advertisements, Venger and Wolburg (2008) examined tobacco advertisements published in periodicals in the US and Ukraine, Lanchester (2010) analyzed message strategies of public service announcements, Lee et al. (2011) reviewed the changes in advertising strategies due to economic crises, James (2011) analyzed the advertisements of luxury brands, Chen and Taylor (2012) scrutinized the content of message strategies of press advertisements that won awards in China International Advertising Festival, Tsai and Lancaster (2012) assessed message strategies applied in pharmaceutical advertisements, Ahn et al. (2013) gauged message strategies of plastic surgery websites, and Brito and Pratas (2016) examined the relationship between the message strategies of online brochures for tourism destinations and the conveyed characteristics.

\section{RESEARCH AND METHODOLOGY}

The presented research questions below are prepared according to previous studies about Taylor's six segment message strategy.

$R Q 1$ : What message strategy is used more often on television advertisements?

RQ2: Among all segments on Taylor's six segment strategy wheel, which ones are most frequently employed on television advertisements?

RQ3: According to the message strategy, is there any differentiation in the advertisements of products and advertisements of services?

$R Q 4$ : Are the two strategies - transmission view and ritual view- used on television advertisements simultaneously?

\subsection{Methodology}

This study is conducted based on quantitative content analysis (Kassarjian, 1977), with the purpose to examine the formats and content of advertisement messages. Content research is evaluated due to two concepts: reliability and validity. Quantitatively measurable reliability, which is handled in connection with the coding process, expresses, in simple terms, consistency. According to Karasar (1984, p. 155), reliability can be defined as; "consistency among independent measurements of the same thing, the thing that is desired to be measured always leading to the same symbols, obtaining identical results by following the same processes and using the same criteria". In Kassarjian's view (1977, p. 13), the importance of reliability lays in the fact that it provides a guarantee for the results to be independent of the measurement, tools or individuals. Interpreting the categories should give similar results among different 
researchers and at different time periods. Shortly explained, interpreting the categories the same way by the same researcher at different times and/or among various researchers provides consistency. Validity, on the other hand, refers to how much or to what extent an instrument measures the thing desired to be measured (Kassarjian, 1977), or, with a more comprehensive explanation, the representability of our measurement regarding the phenomenon we want to acquire knowledge about (Mackey and Gass, 2005, p. 107).

Three different approaches to assess the appropriateness of the measurements are classical test theory (CTT), generalizability theory (GT), and item response theory (IRT). According to CTT various coefficients are calculated for inter-coder agreement. Cohen and Swerdlik (2013, p. 151), state that one of the easiest methods for determining the degree of inter-coder consistency is to calculate correlation coefficient called the inter-coder reliability coefficient. Neuendorf (2002, p. 148), mentioned the availability of different coefficients for ascertaining inter-coder agreement levels. She listed the most popular coefficients applied in social and behavior sciences as raw percent agreement, Scott's pi, Cohen's kappa, Krippendorff's alpha, Spearman's rho and Pearson's r. In CTT, reliability coefficients are commonly measured on a scale of $0-1$, in which being closer to 1 meaning high reliability and being closer to 0 meaning low reliability (Tan, 2013, p. 135). 0.90 and higher values indicate high reliability; values between 0.80 and 0.90 mean medium reliability; and 0.65 to 0.70 indicate weak or low reliability (Cohen and Swerdlik, 2013, p. 151). An overview of studies on reliability reveals that reliability coefficients above 0.90 are accepted in all, results above 0.80 are accepted in most of them (Neuendorf, 2002, p. 143).

Inter-coder reliability is defined as the degree of agreement or consistency of two or more coders about a specific measurement; however, different methods in determining inter-coder reliability are also applied (Cohen and Swerdlik, 2013, p. 150-151).

\section{Figure 1 - Classification of Coder Reliability Coefficients}

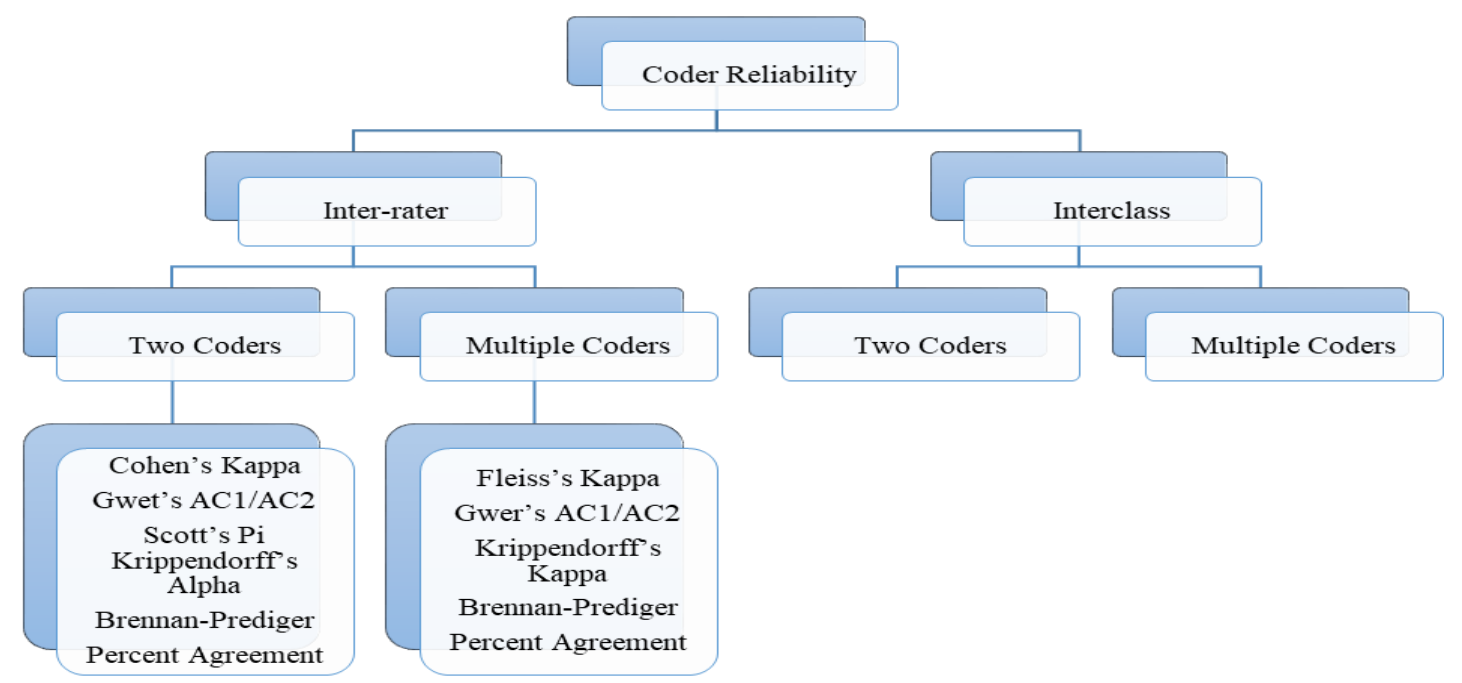

Inter-coder reliability coefficient is an essential statistical tool used frequently by researchers in order to determine the quality of data collection methods. Interobserver/inter-observer, interjudge/inter-judge, and intercoder/inter-coder are alternative terms within literature used for measurements with same characteristics (Gwet, 2001, p. vii).

As it is a two-author work, inter-coder reliability analysis is selected for this study. According to Neuendorf in a study with two or more coders, reliability turns into inter-coder reliability or the 
amount of agreement. Inter-coder reliability reaching an acceptable level is important in terms of creating the basic nature of coding plan and acquiring the advantages of using multiple coders (2002, p. 141-142).

As seen in Table 1, agreement coefficients calculated for two coders are listed as Cohen's kappa, Gwet's AC1/AC2, Scott's pi, Krippendorff's alpha, Brennan-Prediger and Percent Agreement. Agreement coefficients were calculated for two coders with data gathered within the scope of the study. The relationship between agreement coefficients for two coders turned out to be similar in with and without data loss situations. It was determined that the agreement percentage exhibited minimum error and maximum reliability.

Percent agreement is a simple percentage representing the division of agreement number by the total of measurements. The value of this statistic falls between 0.00 and 1.00; 0.00 indicating no agreement, 1.00 indicating perfect agreement. Conceptual formula of percent agreement is as demonstrated (Neuendorf, 2002, p. 149):

$$
\begin{gathered}
\text { PAo }=- \\
\mathrm{A} \\
\mathrm{A} A_{o}=\text { observed percent agreement } \\
\mathrm{N}=\text { number of agreements between two coders } \\
\mathrm{N}=\text { number of units coded by two coders }
\end{gathered}
$$

When calculating percent agreement, the units of agreement occurring by chance are excluded. The ratio of units the coders agreed on for Cohen's kappa, Gwet's AC2, Scott's pi and BrennanPrediger are calculated like percent agreement as well. However, Cohen's kappa, Gwet's AC2 and Scott's pi perform a correction by calculating a ratio for determining agreements-by-chance when calculating the coefficients. Therefore, the agreement coefficient may result in a higher

\begin{tabular}{|c|c|c|c|c|c|c|c|c|c|}
\hline \multicolumn{3}{|c|}{ Transmission View } & \multicolumn{3}{|c|}{ Ritual View } & \multirow{2}{*}{$\begin{array}{l}\text { Number } \\
\text { of Units } \\
\text { Coded }\end{array}$} & \multirow{2}{*}{$\begin{array}{l}\text { Numbe } \\
\text { r of } \\
\text { Agreem } \\
\text { ents }\end{array}$} & \multirow{2}{*}{$\begin{array}{l}\text { Diverge } \\
\text { nce }\end{array}$} & \multirow{2}{*}{$\begin{array}{l}\text { Percent } \\
\text { Agreement }\end{array}$} \\
\hline $\begin{array}{c}\text { Ratio } \\
\text { nal }\end{array}$ & $\begin{array}{l}\text { Acut } \\
\text { e } \\
\text { Nee } \\
\text { d }\end{array}$ & $\begin{array}{c}\text { Routi } \\
\text { ne }\end{array}$ & $\begin{array}{c}\text { Eg } \\
\text { o }\end{array}$ & $\begin{array}{c}\text { Soc } \\
\text { ial }\end{array}$ & $\begin{array}{c}\text { Sens } \\
\text { ory }\end{array}$ & & & & \\
\hline \multicolumn{6}{|l|}{ Food } & 83 & 78 & 5 & 0,939 \\
\hline \multicolumn{6}{|c|}{ Technological and Electronic } & 49 & 46 & 3 & 0,938 \\
\hline \multicolumn{6}{|c|}{ Health and Cosmetic } & 33 & 30 & 3 & 0,909 \\
\hline \multicolumn{6}{|c|}{ Finance } & 21 & 20 & 1 & 0,952 \\
\hline \multicolumn{6}{|c|}{ House Cleaning Supplies } & 12 & 12 & 0 & 1 \\
\hline \multicolumn{6}{|c|}{ Automotive } & 13 & 13 & 0 & 1 \\
\hline \multicolumn{6}{|c|}{ Clothing } & 31 & 30 & 1 & 0,967 \\
\hline
\end{tabular}
value than the other coefficients. The agreement coefficient with the highest agreement value and lowest error is the percent agreement, as no correction is performed for agreements-bychance when calculating it (Ada, 2015).

Table 2 - The Distribution of Coding the Measuring Object by the Coders

\section{Measuring Object}




\begin{tabular}{lllll} 
Trade & 66 & 62 & 4 & 0,939 \\
Other & 12 & 11 & 1 & 0,916 \\
Total & 320 & 302 & 18 & 0,943 \\
\hline
\end{tabular}

Percent agreement for this study was found 0.943. According to Neuendorf's (2002), criteria, the reliability rate is sufficient and the research is deemed reliable. Deliberations were conducted until there was $1.00(100 \%)$ consensus between coders and tabulation of the codes in appropriate themes was provided through this method.

The first condition of a measuring tool to be considered valid is it being reliable. The validity of a test is limited by its reliability. Reliability is the prerequisite for validity. All factors influencing a test's reliability also influence its validity (Tekin, 2008). While Karasar (1984, p. 159), approaches validity in three types as content, execution (experimental), and construction validity, Tekin (2008) examines it in four types as scope, method, construction and appearance validity. According to Tekin's Content (Scope) Validity approach, it is important to what extent each data serves the study as a whole (2008, p. 45). A test with a measuring subject sampling the space sufficiently and balanced, and that every item it includes genuinely measures every behavior intended to be measured can be considered to have content validity. Neuendorf's (2002), criteria state having a sufficient reliability rate demonstrates that the study also has validity.

\subsection{Coding Process}

All coding was conducted by the two authors of the study. Before the coding table was given its final form, another academician with the specific field training was consulted about the coding table and coding instructions, in order to create reliable coding categories. The study was conducted more healthily by constructing it on Taylor's six segment message strategy model and preparing it based on categories, which were used in other studies, available within literature as briefly mentioned above. The coding table was prepared to allow recording the creative message strategy considering the possibility of single or multiple segment use within Taylor's six segment message strategy. When conducting the coding process, researchers were able to watch the commercials more than once, in order to determine the advertisement category and used creative strategy segment. For a few categories, in which agreement could not be provided during the coding process, the aforementioned academician with field training was consulted and a consensus was met.

\subsection{Research Findings}

While Atv, Kanal D, Show TV and Star TV are among private nation-wide television stations, TRT is the first national TV station broadcasting country-wide. Considering the distribution of advertisements among TV stations, apart from TRT, no huge quantitative differences were detected compared to each other.

Table 3 - Advertisement Distribution among Television Stations

\begin{tabular}{lll}
\hline \multicolumn{1}{c}{ Television Stations } & \multicolumn{1}{c}{ Advertisement Distribution } & Rtg\%* \\
\hline Atv & $20 \%(571)$ & 4,92 \\
Kanal D & $22 \%(619)$ & 5,43 \\
TRT & $12 \%(344)$ & 2,49 \\
Show TV & $25 \%(684)$ & 2,76 \\
Star TV & $21 \%(599)$ & 6,12
\end{tabular}


Total

$100 \%(2817)$

${ }^{*}$ According to data provided by TNS for December 2018 total prime time ratings

Within the examined time period, Show TV was identified as the station with most advertisements given $(25 \%, \mathrm{~N}=684)$, followed by Kanal D 22\% ( $\mathrm{N}=619)$, Star TV 21\% $(\mathrm{N}=599)$, and Atv 20\% ( $\mathrm{N}=571)$. Number of advertisements on TRT (12\%, $\mathrm{N}=344)$ is noticeably less than the rest (Table 3 ).

\section{Graphic 2 - Distribution of Transmission View and Ritual View}

\section{Transmissional and Ritual View Distribution}

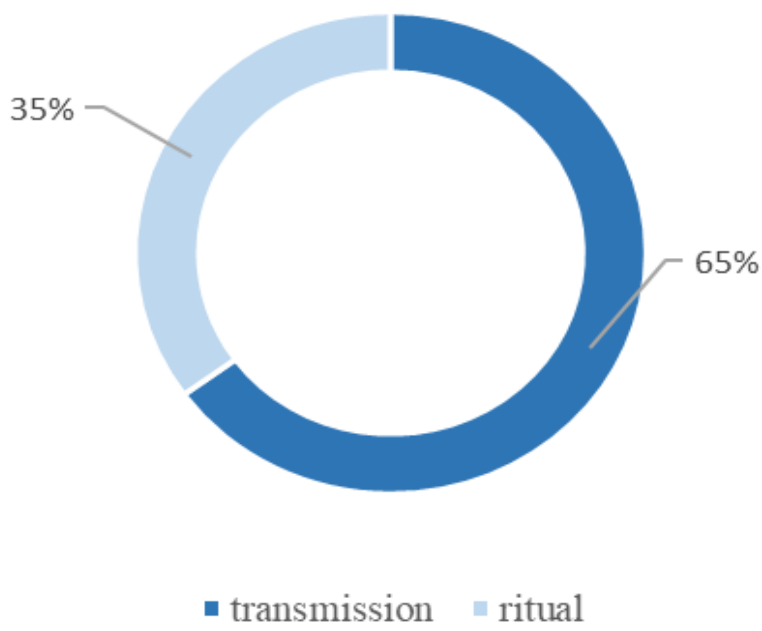

As mentioned above, excluding the reruns, message strategies of 320 advertisements were examined. The analysis revealed that transmission message strategy (rational, acute need and routine), which mostly appeals to consumers' reason and mind by providing information and ideas, was used by $65 \%$. Advertisements including ritual approach (ego, social and sensory), which focuses on senses and emotions of consumers, making statements over consumer beliefs, attitudes and images, had a rate of $35 \%$.

Table 4 - Distribution According to Message Strategy Segments

\begin{tabular}{lllllll}
\hline & & & Frequency & Percent & $\begin{array}{l}\text { Valid } \\
\text { Percent }\end{array}$ & $\begin{array}{l}\text { Cumulative } \\
\text { Percent }\end{array}$ \\
\hline Valid & Transmission & Rational & 94 & 29,4 & 29,4 & 29,4 \\
& view & Acute & 49 & 15,3 & 15,3 & 44,7 \\
& Need & & & & \\
& Routine & 65 & 20,3 & 20,3 & 65,0 \\
& Ritual & Ego & 29 & 9,1 & 9,1 & 74,1 \\
& View & Social & 44 & 13,8 & 13,8 & 87,8 \\
& Sensory & 39 & 12,2 & 12,2 & 100,0 \\
& Total & 320 & 100,0 & 100,0 & \\
\hline
\end{tabular}


When analyzing the message strategy segments placed under transmission and ritual view, rational was identified the most dominant message strategy with a use of $29.4 \%(\mathrm{~N}=94)$ Rational was followed by routine $20.3 \%(\mathrm{~N}=65)$ and acute need $15.3 \%(\mathrm{~N}=49)$, both subsegments of transmission view. Social and sensory segments under the ritual view have proven to have similar amount of application with $13.8 \%(\mathrm{~N}=44)$ and $12.2 \%(\mathrm{~N}=39)$, respectively, leaving ego in the bottom with a use of $9.1 \%(\mathrm{~N}=29)$. According to the three segments of ritual view, no huge distribution difference was detected.

Table 5 - Sectorial Distribution of Advertisements

\begin{tabular}{|c|c|c|c|c|c|}
\hline & & Frequency & Percent & $\begin{array}{c}\text { Valid } \\
\text { Percent }\end{array}$ & $\begin{array}{l}\text { Cumulative } \\
\text { Percent }\end{array}$ \\
\hline \multirow[t]{10}{*}{ Valid } & Food & 83 & 25,9 & 25,9 & 25,9 \\
\hline & $\begin{array}{l}\text { Technological } \\
\text { and Electronic }\end{array}$ & 49 & 15,3 & 15,3 & 41,3 \\
\hline & $\begin{array}{l}\text { Health and } \\
\text { Cosmetic }\end{array}$ & 33 & 10,3 & 10,3 & 51,6 \\
\hline & Finance & 21 & 6,6 & 6,6 & 58,1 \\
\hline & $\begin{array}{l}\text { House Cleaning } \\
\text { Supplies }\end{array}$ & 12 & 3,8 & 3,8 & 61,9 \\
\hline & Automotive & 13 & 4,1 & 4,1 & 65,9 \\
\hline & Clothing & 31 & 9,7 & 9,7 & 75,6 \\
\hline & Trade & 66 & 20,6 & 20,6 & 96,3 \\
\hline & Other & 12 & 3,8 & 3,8 & 100,0 \\
\hline & Total & 320 & 100,0 & 100,0 & \\
\hline
\end{tabular}

The analysis of the distribution according to 9 sectors of the examined 320 advertisements in Turkish television stations showed that the top three sectors are food $25.9 \%(\mathrm{~N}=83)$, product and services in the trade sector $20.6 \%(\mathrm{~N}=66)$, and technological and electronic products $15.3 \%$ $(\mathrm{N}=49)$. The top three are followed by health and cosmetic products with $10.3 \%(\mathrm{~N}=33)$ and the clothing industry with $9.7 \%(\mathrm{~N}=31)$. The other categories did not reveal a significant difference in advertisement distribution (finance 6.6\%, automotive 4.1\%, house cleaning supplies $3.8 \%$, other $3.8 \%$ ).

Table 6 - Sectorial Distribution of Advertisements and Applied Message Strategy Crosstabulation

\begin{tabular}{|c|c|c|c|c|c|c|c|c|c|}
\hline \multicolumn{10}{|c|}{ Advertising Sectors $*$ Message Strategy Cross-tabulation } \\
\hline & & & \multicolumn{6}{|c|}{ Message Strategy } & \multirow[t]{2}{*}{ Total } \\
\hline & & & $\begin{array}{l}\text { rationa } \\
1\end{array}$ & $\begin{array}{l}\text { acute } \\
\text { need }\end{array}$ & $\begin{array}{l}\text { routi } \\
\text { ne }\end{array}$ & ego & $\begin{array}{l}\text { socia } \\
1\end{array}$ & $\begin{array}{l}\text { sensor } \\
\mathrm{y}\end{array}$ & \\
\hline \multirow{3}{*}{$\begin{array}{l}\text { Advertisi } \\
\text { ng } \\
\text { Sectors }\end{array}$} & \multirow[t]{2}{*}{ Food } & Count & 7 & 1 & 27 & 4 & 19 & 25 & 83 \\
\hline & & $\begin{array}{l}\% \text { within } \\
\text { advertisin } \\
\text { g sector }\end{array}$ & $8,4 \%$ & $1,2 \%$ & $\begin{array}{l}32,5 \\
\%\end{array}$ & $4,8 \%$ & $\begin{array}{l}22,9 \\
\%\end{array}$ & $30,1 \%$ & $100,0 \%$ \\
\hline & Tech & Count & 37 & 3 & 2 & 3 & 4 & 0 & 49 \\
\hline
\end{tabular}




\begin{tabular}{|c|c|c|c|c|c|c|c|c|c|}
\hline & $\begin{array}{l}1 \text { and } \\
\text { Electronic }\end{array}$ & $\begin{array}{l}\% \text { within } \\
\text { advertisin } \\
\text { g sector }\end{array}$ & $75,5 \%$ & $6,1 \%$ & $4,1 \%$ & $6,1 \%$ & $8,2 \%$ & $0,0 \%$ & $100,0 \%$ \\
\hline & \multirow{2}{*}{$\begin{array}{l}\text { Health and } \\
\text { Cosmetic }\end{array}$} & Count & 2 & 5 & 9 & 6 & 2 & 9 & 33 \\
\hline & & $\begin{array}{l}\% \text { within } \\
\text { advertisin } \\
\text { g sector }\end{array}$ & $6,1 \%$ & $\begin{array}{l}15,2 \\
\%\end{array}$ & $\begin{array}{l}27,3 \\
\%\end{array}$ & $\begin{array}{l}18,2 \\
\%\end{array}$ & $6,1 \%$ & $27,3 \%$ & $100,0 \%$ \\
\hline & \multirow[t]{2}{*}{ Finance } & Count & 10 & 3 & 2 & 1 & 5 & 0 & 21 \\
\hline & & $\begin{array}{l}\% \text { within } \\
\text { advertisin } \\
\text { g sector }\end{array}$ & $47,6 \%$ & $\begin{array}{l}14,3 \\
\%\end{array}$ & $9,5 \%$ & $4,8 \%$ & $\begin{array}{l}23,8 \\
\%\end{array}$ & $0,0 \%$ & $100,0 \%$ \\
\hline & \multirow{2}{*}{$\begin{array}{l}\text { House } \\
\text { Cleaning } \\
\text { Supplies }\end{array}$} & Count & 0 & 8 & 1 & 0 & 0 & 3 & 12 \\
\hline & & $\begin{array}{l}\% \text { within } \\
\text { advertisin } \\
\text { g sector }\end{array}$ & $0,0 \%$ & $\begin{array}{l}66,7 \\
\%\end{array}$ & $8,3 \%$ & $0,0 \%$ & $0,0 \%$ & $25,0 \%$ & $100,0 \%$ \\
\hline & \multirow[t]{2}{*}{ Automotive } & Count & 7 & 0 & 2 & 4 & 0 & 0 & 13 \\
\hline & & $\begin{array}{l}\% \text { within } \\
\text { advertisin } \\
\text { g sector }\end{array}$ & $53,8 \%$ & $0,0 \%$ & $\begin{array}{l}15,4 \\
\%\end{array}$ & $\begin{array}{l}30,8 \\
\%\end{array}$ & $0,0 \%$ & $0,0 \%$ & $100,0 \%$ \\
\hline & \multirow[t]{2}{*}{ Clothing } & Count & 4 & 6 & 6 & 7 & 8 & 0 & 31 \\
\hline & & $\begin{array}{l}\% \text { within } \\
\text { advertisin } \\
\text { g sector }\end{array}$ & $12,9 \%$ & $\begin{array}{l}19,4 \\
\%\end{array}$ & $\begin{array}{l}19,4 \\
\%\end{array}$ & $\begin{array}{l}22,6 \\
\%\end{array}$ & $\begin{array}{l}25,8 \\
\%\end{array}$ & $0,0 \%$ & $100,0 \%$ \\
\hline & \multirow[t]{2}{*}{ Trade } & Count & 23 & 21 & 12 & 3 & 6 & 1 & 66 \\
\hline & & $\begin{array}{l}\% \text { within } \\
\text { advertisin } \\
\text { g sector }\end{array}$ & $34,8 \%$ & $\begin{array}{l}31,8 \\
\%\end{array}$ & $\begin{array}{l}18,2 \\
\%\end{array}$ & $4,5 \%$ & $9,1 \%$ & $1,5 \%$ & $100,0 \%$ \\
\hline & \multirow[t]{4}{*}{ Other } & Count & 4 & 2 & 4 & 1 & 0 & 1 & 12 \\
\hline & & $\begin{array}{l}\% \text { within } \\
\text { advertisin } \\
\text { g sector }\end{array}$ & $33,3 \%$ & $\begin{array}{l}16,7 \\
\%\end{array}$ & $\begin{array}{l}33,3 \\
\%\end{array}$ & $8,3 \%$ & $0,0 \%$ & $8,3 \%$ & $100,0 \%$ \\
\hline \multirow[t]{2}{*}{ Total } & & Count & 94 & 49 & 65 & 29 & 44 & 39 & 320 \\
\hline & & $\begin{array}{l}\% \text { within } \\
\text { advertisin } \\
\text { g sector }\end{array}$ & $29,4 \%$ & $\begin{array}{l}15,3 \\
\%\end{array}$ & $\begin{array}{l}20,3 \\
\%\end{array}$ & $9,1 \%$ & $\begin{array}{l}13,8 \\
\%\end{array}$ & $12,2 \%$ & $100,0 \%$ \\
\hline
\end{tabular}

According to Chi-Square Test results as $\mathrm{p}=0,000<0,005$, there is a significant relationship between advertising sectors and used message strategy segments. Within this scope, it is striking how close routine $(32.5 \%)$ and sensory $(30.1 \%)$ are to each other in food commercials and how much more they are preferred over other segments. Rational segment under transmission view is employed in $75.5 \%$ of advertisements of technological service and products, whereas the sensory segment in the same advertising category was not applied in message strategies at all.

While routine and sensory segments found equal place with $27.3 \%$ in health and cosmetic products similarly to the food industry, rational and social segments shaped their message strategies with two commercials $(6.1 \%)$ each. The rational segment is the most dominant 
message strategy (47.6\%) in advertisements of finance; with the social segment being the second most used $(23.8 \%)$.

Findings indicate that advertisements especially for home cleaning products prefer acute need segment $(66.7 \%)$. It is remarkable that the advertisement messages of the automotive industry employ the two furthest segments of transmission view and ritual view. The structure of message strategies of automotive advertisements is based on rational (53.8\%), which attempts to satisfy the information need, and ego (30.8\%), in which the emotional approach is intense.

The clothing industry, on the other hand, does not use one dominant message strategy, with a very close distribution among social, ego, routine and acute need. Sensory segment was not used in any advertisement. For the trade sector, big part of advertisement messages includes the three segments placed under transmission view. The distribution within this scope is: rational $34.8 \%$, acute need $31.8 \%$, and routine $18.2 \%$.

\section{CONCLUSIONS AND DISCUSSIONS}

The results of this study are based on advertisements broadcast on Turkish national television. The examined advertisements including various product categories, advertisement types and brands represent a general composition of daily advertisements. Within this context, assessment of research questions together with the obtained findings revealed the cases explained below:

$R Q 1$ : What message strategy is used more often on television advertisements?

Upon examining the advertisements broadcast during prime time on 5 TV stations with the highest ratings in December 2018 according to Taylor's six segment strategy wheel, it was determined that transmission view $(65 \%)$ was the dominantly used message strategy. It was disclosed that in 208 of 320 examined advertisements, message strategies aiming to inform the consumer were more dominantly used. It is clear that advertisement messages trying to capture the consumers cognitively with content including price, sales conditions, and product characteristics were used aiming to promote product/service purchase. Ritual view is observed in a few number of advertisements $(35 \%, \mathrm{~N}=112)$.

RQ2: Among all segments on Taylor's six segment strategy wheel, which ones are most frequently employed on television advertisements?

Parallel to the findings obtained from the first research question, it was determined that rational within transmission view was the most dominantly preferred $(29.4 \%)$ segment in advertisement messages. Analyzed ads revealed that routine was used in $20.3 \%$ and acute need in $15.3 \%$. With being observed in $13.8 \%$ and $12.2 \%$ of the advertisements, social and sensory segments under the ritual view have proven to have a similar amount of application rate. Ego turned out to be the least preferred segment with $9.1 \%$.

$R Q 3$ : According to the message strategy, is there any differentiation in the advertisements of products and advertisements of services?

As expressed in the findings, significant relationship between product/service advertisements and used message strategies was found. Review of data in terms of sectorial distribution of advertisements revealed that the biggest share was of food commercials with $25.9 \%$, routine being the prominent segment. In addition, social and sensory segments were observed to take place in message strategies of food advertisements. Considering the consumer need for information in technology based products and services, rational segment is preferred in the message strategies of these advertisements. Similarly, finance, automotive and trade commercials' message strategies mostly comprise rational segment. As expected, acute need is the segment preferred for house cleaning products. While message strategies of health and cosmetic products are mostly constructed on routine and sensory, the message strategies of clothing industry exhibit an equal distribution among segments. 
RQ4: Are the two strategies - transmission view and ritual view- used on television advertisements simultaneously?

In Taylor's six segment message strategy model clients are able to choose between using one advertising approach (e.g. ego) or a combination of two approaches (e.g. ego and sensory) (Taylor, 1999, p. 9). However, reviewed sample has shown only 3 advertisements in which the researchers did multi-coding. As those 3 ads have no significant representative power, data could not be formed for combined strategies or segments.

Although not being analyzed in terms of content aspect, the research provides a view of economic, social and political changes in Turkey especially for the period of December 2018. The change of the political regime of the country shortly prior to the research has also deeply impacted economic indicators and caused significant transformation in social life. The research results for the Turkish economy of 2018 conducted by Turkish Statistical Institute, which is a research institute connected to the Ministry of Development, indicated a serious setback in domestic demand due to the inflation caused especially by the drastic increase in foreign exchange rates. According to Eğilmez, these circumstances lead to an increase of unemployment rates starting mid-2018 and, therefore, in an environment where production and growth decreases and unemployment increases, demand naturally decreased (Eğilmez, 2018).

Purchasing power of minimum wage for various basic need items was lost by half according to the results of the study announced in December 17, 2018, conducted by United Metal Workers' Union Research Center (BİSAM) with data provided by TÜIK (Turkish Statistical Institute TurkStat) Prices, CPI and Turkish Ministry of Family, Labor and Social Services. Comparing data of November 2016 to November 2018 revealed that the minimum wage earner lost their purchasing power in 334 products among 389. So, the minimum wage earners experienced loss in 86 of 100 products. A huge number of companies filed for concordat especially due to the extreme increase of foreign exchange rates. Turkish Minister of Trade announced in her statement in December 27, 2018 that 979 companies had filed concordat (Özkan, 2019)

Under the light of these data, the decrease of the purchasing power of the consumers is an important determinant for advertisers as well. Since consumers are being drifted towards cautious consumption due to the overall economic atmosphere of the country, their need for cognitive-based consumption increases rather than their sensory and emotional satisfaction. As consumers are forced to restrain their tendencies for self-realization, socializing, emotions and pleasure, it is believed that different sectors are becoming inclined to use more advertisement messages focusing on price, product information and sales motivation. This inclination is considered as the reflection of consumer's decline of purchasing power. Studies supporting this view are available in literature (Carey, 1960; Everett, 1988; Lee et al., 2011).

\section{LIMITATIONS AND FURTHER RESEARCH}

This study examined only television advertisements for a limited time period. Considering that the limits of media are far beyond television since the introduction of internet and social media, this study can be proceeded with inclusion of advertisements broadcast in these fields.

Furthermore, the study can be developed by conducting comparisons between the advertisements with same product category in other countries. Alternatively, the examined time period can be expanded through periodical reviews, allowing researchers to detect whether there is any change in used message strategies in television advertising over the course of time.

Finally, as a distinct research topic, the social and economic changes mentioned in the $5^{\text {th }}$ chapter of the study can be examined to determine what sort of an impact they have on message strategies (e.g. comparing prior to, during and after). 


\section{REFERENCES}

Ahn, H.; Wu, L. and Taylor, R. E. (2013). Communication Strategies in Cosmetic Surgery Websites: An Application of Taylor's Six-Segment Message Strategy Wheel, Health Marketing Quarterly, Vol. 30.97-113.

Ada, S. (2015). Klasik Test Kuramına Göre Sayısal Ve Sözel Alanlar İçin Puanlama Güvenirliğinin Kayıp Veri Kapsamında İncelenmesi, Yayımlanmamış Yüksek Lisans Tezi, Gazi Üniversitesi Eğitim Bilimleri Enstitüsü, Ankara.

Baack, D.W., Wilson, R.T., Van Dessel, M.M., and Patti, C.H. (2016). Advertising to businesses: Does creativity matter?. Industrial Marketing Management, 55, 169-177.

Brito, P. Q. and Joaquim, P. (2016). Online brochures: relationship between message strategies and communicated attributes, Anatolia, 27:1, 47-57.

Carey, J. W. (1960). Advertising: An institutional approach. Charles H. Sandage \& Vernon Fryburger (ed.) In The Role of Advertising in Society (3-17), Homewood: Irwin.

Chen, H. and Taylor, R. (2012). Message Strategies of Chinese Award-Winning Print Advertisements A Longitudinal Analysis Using Taylor's Six-Segment Message Strategy Wheel, Journal of Intercultural Communication, ISSN 1404-1634, issue 30.

Cohen, R. J., and Swerdlik, M. E. (2013). Psikolojik Test ve Değerleme Testlere ve Ölçmeye Giriş, Ankara: Nobel.

Deloitte, (n.d.). Türkiye'de Tahmini Medya ve Reklam Yatırımları. Retrieved from https://www2.deloitte.com/tr/tr/pages/technology-media-and-

telecommunications/articles/turkiyede-tahmini-medya-ve-reklam-yatirimlari.html,

Elden, M. (2003). Reklam Yazarlığı. İstanbul: İletişim Yayınları.

Eğilmez, M. (2018, December 28). 2018'den 2019'a Geçerken Türkiye Ekonomisinin Görünümü, Retrieved from http://www.mahfiegilmez.com/2018/12/2018den-2019agecerken-turkiye.html.

Everett, S.E. (1988). Financial services advertising before and after the crash of 1987. Journalism Quarterly, 65(4), 920-924.

Frazer, C. (1983). Creative strategy: A management perspective. Journal of Advertising, 21, 3641.

Hwang, J., McMillan, S. and Lee, G. (2003). Corporate web sites as advertising: An analysis of function, audiences, and message strategy. Journal of Interactive Advertising, 3, 12-32.

Golan, G., and Zaidner, L. (2008). Creative strategies in viral advertising: An application of Taylor's six-segment message strategy wheel. Journal of Computer-Mediated Communication, 13, 959-972.

Gwet, K. (2001). Handbook of inter-rater reliability. Gaithersburg: Stataxis.

James, W. M. (2011). The appeals of luxury advertising: An application of Taylor's six-segment message strategy wheel. The Elon Journal of Undergraduated Research in Communications, 2, 62-75.

Koslow, S. (2014). I Love Creative Advertising What It Is, When to Call for It, And How to Achieve It, Journal of Advertising Research, 5-8.

Kassarjian, H.H. (1977). Content analysis in consumer research, Journal of Consumer Research, $4(1), 8-18$.

Kim, J., Sally J. M. and Jang-Sun, H. (2005). Strategies for the Super Bowl of Advertising: An Analysis of How the Web is Integrated into Campaigns, Journal of Interactive Advertising, 6(1), 46-60. 
Lancaster, A. (2010). Can Taylor's six-segment message strategy wheel be applied to public service advertising? Paper presented at the AAA 2010 Conference, Minneapolis, Retrieved from http://shodhganga.inflibnet.ac.in/bitstream/10603/97366/2/chapter\%202.pdf,

Laskey, H. A., Day, E., and Crask, M. R. (1989). Typology of main message strategies for television commercials. Journal of Advertising, 18, 36-41.

Lee, G. (2000). Differences in the use of message strategies between the U.S. and Korean television automobile commercials. Paper presented at the National Conference of the Association for Education in Journalism and Mass Communication, Phoenix, AZ.

Lee, G., Kyoungtae J. N. and Hwang J. (2001). Message strategies of American and Korean television commercials. In C. R. Taylor (Ed.), The proceedings of the 2001 conference of the American academy of advertising (pp. 29-30). Salt Lake City: American Academy of Advertising.

Lee, T., Chung, W., and Taylor, R. (2011). Changes in advertising strategies during an economic crisis: An application of Taylor's six-segment message strategy wheel. Journal of Applied Communication Research, 39, 75-91.

Mackey, A. and Susan M. G. (2005). Second Language Research: Metodology and Design. New York:Rouledge.

Moriarty, S. E. (1991). Creative Advertising Theory and Practice. New Jersey: Prentice Hall.

Morrison, M. and White, C. (2000). Super.com: An analysis of message strategies utilized in super bowl ads for dot.com companies. Paper presented at the Association for Education in Journalism and Mass Communication conference, Phoenix.

Neuendorf, K. A. (2002). The Content Analysis Guidebook, Sage Publications, Thousand Oaks.

Özkan, B. (2019, March 7). Konkordato ilan eden şirket sayısı 2 aydır açıklanmadı. Retrieved from https://www.sozcu.com.tr/2019/ekonomi/konkordato-ilan-eden-sirket-sayisi-2aydir-aciklanmadi-3819094/

Politz, A. (1960). The Dillemma of Creative Advertising. Journal of Marketing, October, 1-6.

Samati, A. and Khalili, H. (2017). Influence of in-store and out-of-store creative advertising strategies on consumer attitude and purchase intention, Intangible Capital, 13(3), 523547.

Smith, R.E. and Yang, X. (2004). Toward a General Theory of Creativity in Advertising: Examining the Role of Divergence. Marketing Theory, 4(1-2), 31-58.

Taylor, R. (1999). A six-segment message strategy wheel. Journal of Advertising Research, 39, $7-17$.

Taylor, R. E., Hoy, M. G., and Haley, E. (1996). How French advertising professionals develop creative strategy. The Journal of Advertising, 25(1), 1-14.

Tsourvakas, G., Kyriakos, R. and Ioanna, Y. (2017). Advertising message strategy analysis for award-winning digital ads, International Journal of Technology Marketing, 12(4). 340355 .

Tsai, W., and Lancaster, A. (2012). Message strategies in direct-to-consumer pharmaceutical advertising: A content analysis using Taylor's six-segment message strategy wheel. Health Marketing Quarterly, 29, 239-255.

Yang, K. and Jolly, L.D. (2008). Age cohort analysis in adoption of mobile data services: gen Xers versus baby boomers, Journal of Consumer Marketing, 25(5), 272-280. 
Zenith Media, (n.d.). Advertising Expenditure Forecasts March 2018. Retrieved from https://www.zenithmedia.com/wp-content/uploads/2018/03/Adspend-forecasts-March2018-executive-summary.pdf,

United Metal Workers' Union Research Center, (2019). Retrieved from, http://www.turkmetal.org.tr/

Turkish Statistical Institute, (2019). Retrieved from, http://tuik.gov.tr

Turkish Ministry of Family, Labor and Social Services, (2019). Retrieved from, 7https://www.ailevecalisma.gov.tr/7 